\title{
Owning Immigration: Messenger Ethnicity, Issue Ownership, and Support for Latino Candidates
}

\author{
Allyson Shortle and Tyler Johnson \\ The University of Oklahoma
}

\begin{abstract}
The public opinion literature stresses the importance of source cues in determining which types of messages affect attitudes and which types do not. Building upon such research, we seek to determine if messenger ethnicity influences how individuals evaluate candidates speaking on immigration in the context of a campaign. Do Americans (and Anglo Americans in particular) view Latino candidates as more experienced, stronger leaders, more trustworthy, and more qualified on immigration than Anglo candidates? Moreover, do such relationships hold regardless of the valence of the message itself? Through an original survey experiment presenting subjects with immigration talk on the campaign trail, we find Latino candidates are reviewed more positively than Anglo candidates when it comes to the immigration messages they speak (especially when it comes to pro-immigration messages). Such findings give us insight into whether or not Latino candidates have the potential to "own" the issue of immigration, as well as offering another path by which Latino candidates can gain a strong foothold with the public in the context of a campaign.
\end{abstract}

Keywords: issue ownership, immigration, campaigns, Latino politics.

\section{INTRODUCTION}

Latino candidates represent an emerging group of political contenders in the United States (Barreto 2007a; 2007b). The 2012 election provided ample evidence of this, with a majority of Latino congressional candidates (31 out of 49) achieving victory on Election Day (Terrero 2012). This trend of Latino winners causes us to ask what leads Americans to react 
positively toward members of this growing pool of candidates. According to some (Kam 2007), shared partisanship between candidate and citizen drives support, a finding compatible with political science scholarship pointing to the significant and enduring effect of party identification in shaping political attitudes (e.g., Campbell et al. 1960; Green, Palmquist, and Schickler 2004). To others (Barreto 2007a; 2007b), shared ethnicity drives support, with Latinos willing to cross party lines to support Latino candidates. Such a finding is consistent with research on how minority status mobilizes and garners support for minority candidates (Banducci, Donovan, and Karp 2004; Barreto 2007a; 2007b; Barreto, Segura, and Woods 2004; Bobo and Gilliam 1990; Leighley 2001; Manzano and Sanchez 2010; Tate 1993). While these frameworks speak to how co-partisans and co-ethnics might be more or less prone to supporting a Latino candidate, they fail to completely address another path by which individuals assess politicians: the discussion of issues. In this research, we explore how the use of issues might benefit Latino candidates in the minds of citizens. More specifically, we examine whether or not discussing immigration helps Latino candidates in terms of evaluations from individuals. Approaching this question through the framework of issue ownership, we inquire into whether or not Latino candidates receive more positive assessments after discussing immigration than Anglo candidates. The presence of such positive evaluations might be owed to the fact that individuals perceive Latino candidates to have an existing relationship with the issue of immigration, leading individuals to find said candidate experienced, qualified to speak, trustworthy, and able to lead on the issue.

We answer these questions using an original survey experiment. Our results offer strong statistical evidence that individuals do in fact use ethnic cues to convey information about Latino candidates' abilities relating to immigration; these effects also hold across respondent ethnicity and somewhat across the valence of the immigration message offered as well. The results speak to the potential power of Latino candidates to "own" the issue of immigration within the context of a campaign (Petrocik 1996), providing another path by which race might be used as a "strategic advantage" (McIlwain and Caliendo 2011, 43). Such findings also call into question strategies of mainstreaming (e.g. Stuckey, Curry, and Barnes 2010) or "deracialization" employed by candidates seeking to, as Juenke and Sampaio $(2010,44)$ put it, "maximize issues and language that appeal broadly to constituents of many different races and ethnicities." 


\section{ISSUE OWNERSHIP AND WHY LATINO CANDIDATES MIGHT OWN IMMIGRATION}

Existing research has made clear that the public often perceives differences between political parties (and their members) when it comes to the ability to address specific issues, handle specific problems, or embody specific traits (Ansolabehere and Iyengar 1994; Belanger 2003; Budge and Farlie 1983; Doherty 2008; Dulio and Trumbore 2009; Goble and Holm 2009; Hayes 2005; Holian 2004; Petrocik 1996; Petrocik, Benoit, and Hansen 2003; Pope and Woon 2009; Stubager and Slothuus 2013; Walgrave, Lefevere, and Nuytemans 2009; Walgrave, Lefevere, and Tresch 2012). This concept is referred to in the literature as issue ownership. As Petrocik $(1996,826)$ describes in his groundbreaking analysis of issues and presidential elections, issue ownership is built upon a "history of attention, initiative, and innovation" on the part of one party when compared with another. Based upon existing issue ownership, strategic candidates for office take note of where their party's strengths lie and attempt to maximize on said strengths. Issue ownership provides ammunition for candidates from the day they become their party's nominee; it gives candidates the "perception of credibility" (Damore 2004, 392) and links them with "superior policies and programs" (Petrocik, Benoit, and Hansen 2003, 601) in the eyes of many individuals.

While most research on issue ownership has been limited to which parties own which issues, a smaller body has noted how different types of candidates, regardless of party affiliation, might be able to own issues to their electoral advantage. Kaufmann (2004), in her examination of the issue ownership concept, notes that candidates are more easily able to make use of issues on which they have an existing record of performance. More broadly than just issue ownership, Sellers (1998) addresses the concept of candidate backgrounds being a useful tool on the campaign trail. Related literature (some of which directly uses the concept of issue ownership) has also moved toward candidate demographic traits (such as gender) and the strategic use of issues to build support (Alexander and Andersen 1993; Fridkin and Kenney 2009; Herrnson, Lay, and Stokes 2003; Huddy and Terkildsen 1993; Israel-Trummel n. d.; Kahn 1992; Koch 1999; Lawless 2004). Herrnson, Lay, and Stokes (2003), for example, have shown that female candidates benefit from highlighting "compassion" issues (i.e., education, poverty alleviation, income redistribution). Gender can serve as an asset, especially for female candidates who can successfully leverage issues "owned" by women. Despite 
these findings on gender, we still know very little concerning the extent to which issue ownership might affect candidates of other demographic subgroups, including Latino candidates.

Much as Walgrave, Lefevere, and Tresch (2012) find an "associative dimension" of issue ownership (wherein a spontaneous link exists) between political parties and issues in the minds of citizens, we argue a similar link exists between Latino candidates and the issue of immigration. This link springs forth from the experiential and statistical associations between Latinos and immigration built up over time in the minds of Americans. Latino immigrants currently represent the largest group of immigrants in the United States (U.S. Census 2010). Likewise, Latinos are more likely to know or have been related to recent immigrants to the United States, and are more likely than other ethnic groups to identify as immigrants themselves (Barreto 2007a; 2007b; Citrin et al. 1997; Pew 2009). As a result, there is a strong tendency for Americans to organize their thoughts about Latinos alongside the issue of immigration, with recent evidence suggesting that Americans sometimes view immigrants and Latinos as synonymous groups (Masuoka and Junn 2013; Ramakrishnan et al. 2009). As a result of these findings, an existing relationship with the issue of immigration becomes, as Sigelman et al. (1995) might say, an "assumed characteristic" of Latino candidates. Latino candidates who discuss immigration should be able to "activate existing predispositions" (Mendelberg 2001, 121) about the link between this ethnic group and this issue. Talking about immigration primes these existing associations in the minds of citizens for the benefit of Latinos on the campaign trail.

Existing theories of cue-based processing provide additional useful frameworks to support our argument, as they predict a positive relationship between who a candidate is, his or her skill set, and the likelihood that an individual expresses favorable opinions about that candidate. Candidates strongly and positively associated with an issue in the minds of the public should be able to persuade individuals to accept their abilities on the issue (i.e., adopting favorable opinions of a candidate), potentially generating a state of issue ownership over time, whereas non-credible "issue trespassing" candidates are unlikely to be perceived as well in this regard (Iyengar and Valentino 2000). This argument is compatible with past studies, which have shown that across many contexts, messenger characteristics (including those linked with race) tend to be more persuasive in swaying individuals than the content of the political messages they espouse (Arceneaux and Kolodny 2007; Iyengar and Valentino 2000; McDermott 
1997; 1998; Nelson and Garst 2005; Rahn 1993). The source of each message delivered during the campaign, or "who said it," has great potential to explain public opinion in the United States since Americans rate low in political knowledge, display lackluster information processing tendencies, lack the motivation to process the overwhelming information environment of modern day campaigns, and at times struggle to determine how to evaluate candidates (Converse 1964; 1990; Delli Carpini and Keeter 1996; Gilens 2001; Lau and Redlawsk 2001; Zaller and Feldman 1992). As such, Americans often rely upon source cues or traits (such as a messenger's ethnicity, race, or gender) because they lack the ability to comprehensively analyze the costs and benefits associated with each candidate to come to a fully informed decision (Converse 1964; Hayes 2010; Hovland et al. 1953; Koch 2000; Kuklinski and Hurley 1994; Lau and Redlawsk 2001; Lodge, McGraw, and Stroh 1989; Rahn 1993). Source cues such as the name of a candidate might be especially important in low-information electoral or decisionmaking contexts (Butler and Broockman 2011; Matson and Fine 2006; McDermott 1997; 1998).

Given the link between Latinos and immigration in the minds of Americans, we expect to see a positive and significant effect of a candidate's Latino ethnicity upon trait scores - trustworthiness on immigration, strength of leadership on immigration, qualification to discuss immigration, and experience on immigration - as compared with an Anglo candidate, ceteris paribus. Furthermore, given the aforementioned literature on messengers trumping messages, we inquire into whether this effect may exist for multiple types of potential messages. We expect Latino candidates voicing "pro-immigration" stances to be rated higher than Anglo candidates who voice "pro-immigration" stances, but might Latino candidates expressing "anti-immigration" stances be rated higher than Anglo candidates who voice the same "anti-immigration" stances as well? In other words, is the reach of issue ownership by Latino candidates strong enough to encompass both sides ("pro" or "anti") of the issue itself?

Existing findings are inconsistent on this question of whether issue ownership holds across issue position. Research in race and politics suggests that "pro-immigration" messages might provide a level of issue congruence with "assumed characteristics" of Latino candidates, which would play favorably among the public, in a way that "anti-immigration" messages might not (Sigelman et al. 1995). This would mean we should expect Latino candidates voicing "pro-immigration" messages to receive the most positive evaluations on their relationship with the issue of 
immigration. The evidence from the related gender and politics research, however, concludes that candidate characteristics hold sway regardless of issue position. Since the evidence here is mixed, we expect overall that immigration is an issue that the public associates favorably with Latino candidates, much like compassion issues are ones that the public associates favorably with female candidates. However, we formulate no expectations about whether both directions of the Latino candidate's message ("pro" or "anti") should reflect the advantage gained by the candidate's ethnicity. Our research design will allow us to test these expectations as well as answer these questions.

\section{EXPERIMENTAL PROCEDURE}

In order to test whether candidate ethnicity serves as a cue that affects attitudes in this issue area, we conducted an original survey experiment. The subjects were 350 students in introductory-level American Government and Politics courses and upper-level Political Science courses at a southern university in late 2012. ${ }^{1}$ Students were told they were participating in an exercise in which they would evaluate congressional candidates appearing at a public forum. After signing consent forms, students began by filling out a short pre-treatment questionnaire (the details of which can be found in Appendix A). ${ }^{2}$

Following completion of the pre-treatment questionnaire, participants read a simulated Associated Press news story on a fictional state senator who was running as the Democratic nominee for the U.S. House of Representatives to represent Missouri's 6th congressional district. Examples of these stories can be found in Appendix B. The general premise of the story (across all treatments) was that this candidate was appearing at a public forum at the University of Missouri-Kansas City to talk about important issues, but the focus of the story was the candidate's opinions on undocumented immigrants. 3,4

The story participants received, however, varied from one participant to the next in two distinct ways: the name of the candidate and the message from the candidate. Some individuals received a story in which the name of the candidate was Luis Ramírez, while others received a story in which the name of the candidate was Robert Rooney. Such names were chosen to attempt to send participants clear signals that the former candidate was Latino while the latter was Anglo. ${ }^{5}$ Such choices are in keeping with a breadth of research employing similar experimental designs (using a 
name to signal ethnic identity) to examine the impact of minimal cues on evaluations (Abrajano, Nagler, and Alvarez 2005; Bertrand and Mullainathan 2004; Butler and Broockman 2011; Carlsson and Rooth 2007; Fryer and Levitt 2004; Holbrook, Fessler, and Navarrete 2016; Oreopoulos 2011; Riach and Rich 2002). The control group received a more general story in which the candidate had no name.

As for the candidate's message, some individuals participating received a story in which their candidate espoused the positive impact that undocumented immigrants have on American society, while others taking part received a story in which their candidate spoke of the negative impact of undocumented immigrants. Those receiving a story on the positive impact of undocumented immigrants read about how their candidate believed more visas should be granted, that undocumented immigrants take jobs Americans don't want, and that current policies block paths to citizenship and higher education. Those receiving a story on the negative impact of undocumented immigrants read about how their candidate believed that the immigration status of workers should be checked, that undocumented immigrants were taking jobs Missourians wanted, and that the children of undocumented immigrants caused problems related to tuition rates. ${ }^{6}$ Participants in the control group received no positive or negative information about undocumented immigration and were just told that the nameless candidate addressed immigration policy at the forum. Each story mentions three times (once in each of the story's three paragraphs) that the candidate is the Democratic candidate/ nominee in this congressional race; by holding party affiliation constant across all treatments, respondents could focus on the candidate's name and message on immigration. The manipulation of the candidate's ethnicity and message leaves us with five treatments to which participants were randomly assigned: Latino/Pro-Immigration, Latino/Anti-Immigration, Anglo/Pro-Immigration, Anglo/Anti-Immigration, and Control.

After reading the story, participants answered a post-treatment questionnaire asking for assessments of the candidate about whom they just read. This questionnaire asked respondents to evaluate general traits of the candidate in the story. The questionnaire then asked respondents to assess the candidate's strengths and weaknesses specifically related to the issue of immigration. We use four trait measures from the post-treatment questionnaire as the main dependent variables for our analysis: a candidate's experience on immigration, qualification to discuss immigration, trustworthiness on the issue of immigration, and strength to lead on immigration legislation. ${ }^{7}$ Respondents rated the candidate in their treatment on 
these traits using a five-point Likert scale. The questions from this posttreatment questionnaire that comprise our dependent variables can be found in Appendix C.

\section{FINDINGS}

Our analyses of the four immigration-related traits just discussed are presented in two empirical sections, which ultimately will demonstrate: (1) whether and to what degree candidate evaluations differ across treatments that vary by candidate ethnicity and message content, and (2) what the main effect is (as well as its size) driving candidate assessments once we control for alternative explanatory variables. In the latter portion of our analysis, we also present evidence that supports the claim that Americans, even Anglo Americans who should prefer Anglo candidates according to psychological theories (Allport 1954; Brewer 1999; Conover 1984; Tajfel 1981), view Latino candidates as owners of the immigration issue. More generally, the findings indicate that, in the context of a campaign, both messenger ethnicity and message content have the power to shape respondent assessments of candidates on the issue of immigration.

A comparison of favorable evaluations by candidate ethnicity in Figure 1 first shows a consistent trend, where experimental participants rated Latino candidates more favorably than Anglo candidates on the issue of immigration. This occurred regardless of which issue trait we analyzed. For example, $67 \%$ of participants in the Latino condition rated the candidate favorably on strength to lead, compared with just $53 \%$ of participants in the Anglo condition. The trend of assigning favorable evaluations to Latino candidates repeats for the measure about candidate qualification, which yielded a $74 \%$ versus $51 \%$ gap between Latino and Anglo treatment groups. The Latino/Anglo evaluation gap persisted on the experience measure $(69 \%$ versus $36 \%$ ) as well as for the trustworthy evaluation, where $67 \%$ versus $46 \%$ expressed favorable candidate evaluations. Figure l's findings overall indicate a clear trend of favorable evaluations for Latino candidates over Anglo candidates on the issue of immigration. ${ }^{8}$ To further investigate the significance of ethnic cues and message content, we conducted analysis-of-variance (ANOVA) comparisons, which corroborate the statistically significant relationship between the candidate ethnic cue and respondent evaluations. ${ }^{\text {? }}$

The ANOVA results show that when exposed to treatments in which a Latino candidate delivered a pro-immigration message, respondents rated 


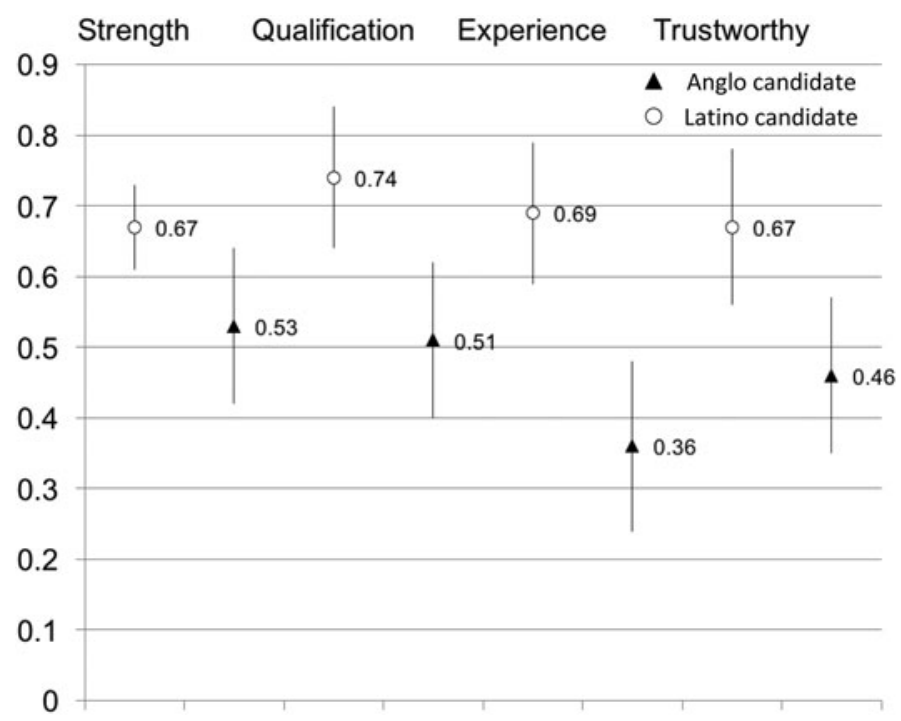

FIgURE 1. Favorable trait evaluations, by candidate ethnicity.

Notes: Proportion of favorable candidate evaluations with $95 \%$ confidence intervals across traits related to handling of immigration. Participants offer higher evaluations for the Latino candidate across all traits.

the candidate significantly more positively than those who received a treatment in which an Anglo candidate delivered the very same pro-immigration message. For the trait of strength of leadership on immigration, there was a mean score of 3.75 out of 5 assigned to the candidate by respondents in the Latino candidate group compared with a 3.36 assigned by respondents of the Anglo candidate group $\left(F_{(1,145)}=6.57, p=.001\right) .{ }^{10}$ This significant effect was similar for respondent ratings of candidate qualifications to discuss the issue of immigration, which resulted in a mean score of 3.85 for the Latino candidate group, compared with the 3.51 score assigned to the candidate by respondents in the Anglo candidate group $\left(F_{(1,145)}=5.95, p=.016\right)$. On the trait measure for candidate experience on immigration, respondents in the Latino treatment group rated the candidate as 3.74 out of a possible 5 , which was significantly higher than the 3.16 that respondents of the Anglo candidate group $\left(F_{(1,145)}=\right.$ $13.75, p=.0003)$. Slightly less clear are attitudes related to trustworthiness on immigration, with a mean score of 3.64 on this trait for those in the Latino candidate group, versus 3.36 for those in the Anglo treatment group $\left(F_{(1,145)}=3.27, p=.073\right)$. While these differences vary in size, with some appearing smaller than others, the comparisons from the 
ANOVA analyses ultimately result in high levels of statistical significance, with one case producing near-significant results.

Substantively, these differences illustrate that respondents receiving pro-immigration messages from an Anglo candidate were likely to offer mid-range, or neutral, evaluations for all the traits being examined. This outcome seems reasonable, since respondents knew very little about the candidate's immigration stance other than what can be gleaned from a short story. We would expect respondents to assign neither overly positive nor negative evaluations about this fictional candidate's ability to handle the issue of immigration based on this information. Respondents that were exposed to our Latino candidate treatment with the same exact pro-immigration message, however, offered evaluations that were distinctly more positive about the candidate's relationship with the issue of immigration.

In comparing Latino candidates and Anglo candidates delivering antiimmigration messages, we do at least find one significant difference in respondent assessments of traits. That difference lies in the extent to which the respondents found the candidates qualified to discuss immigration. The Latino candidate delivering an anti-immigration message received an average score of 3.31 out of 5 when it comes to qualification to discuss immigration, while the Anglo candidate delivering the exact same message received an average of $2.99\left(F_{(1,145)}=3.99, p=.048\right)$. The remaining results of the anti-immigration comparisons continue to demonstrate consistently higher mean scores for Latino candidates over Anglo candidates, despite their statistical insignificance. For example, evaluations resulted in mean scores of 3.44 for the Latino candidate versus 3.22 for the Anglo candidate on the trait of strength of leadership $\left(F_{(1}\right.$, 143) $=2.02, p=.157), 3.13$ for the Latino candidate versus 3.07 for the Anglo candidate on the trait of trustworthiness on immigration $\left(F_{(1,143)}\right.$ $=.14, p=.70)$, and 3.06 for the Latino candidate versus 2.86 for the Anglo candidate on the trait of experience on immigration $\left(F_{(1,143)}=\right.$ $1.31, p=.25)$.

We can infer from the significant findings (given that the only difference across pro-immigration messages was the name of the candidate) that the ethnic cue, as it turns out, was important information in the formation of these evaluations. However, unlike the typical scenario where that ethnic information is used to the detriment of minority candidates, in this case, the ethnic minority candidate benefits from this information. When it comes to the population at large, Latino candidates likely derive benefits from their ethnicity when delivering pro-immigration messages. In this context, there is ownership of this issue based on name alone. 
All of the evidence from the pro-immigration ANOVA tests, considered together, ultimately suggests the existence of a Latino issue ownership effect.

Next, we employ multivariate empirics to investigate the Latino issue ownership effect controlling for a host of relevant covariates. We further incorporate tests of the claims that pro-immigration and anti-immigration messages could be linked to higher evaluations of candidates. While we have some reason to suspect one type of message will lead to positive evaluations, the literature supports the association of certain messages with candidate evaluations (i.e., Druckman 2004; Fridkin and Kenney 2009), which is why we now turn our focus towards a test of these hypothetical claims. In addition, we include a more thorough examination of whether Anglo respondents differ substantially from the full sample of respondents (Abosch, Barreto, and Woods 2007; Barreto 2007a; 2007b; 2010; Barreto, Segura, and Woods 2004; Dawson 1994; Tate 1993). We focus on the same four traits of strength of leadership, qualification to discuss, trustworthiness, and experience on immigration. We also include individuals who received the control treatment into the analysis. Due to the categorical nature of the dependent variables, we employed ordered probit models. Finally, for ease of interpreting the coefficients, predicted probabilities were generated to get a better picture of the size of the effects in respondent evaluations when moving from the Anglo candidate to the Latino candidate.

The multivariate analysis corroborates the findings of the bivariate analyses in terms of candidate ethnicity effects - Latinos continue to "own" the issue of immigration, for all traits. Table 1 illustrates that the Latino treatment is a highly significant predictor of positive candidate evaluations on immigration, holding all else equal. The Latino treatment retains significance when controlling for respondent partisanship, sex, income, identification as Latino, and prior immigration attitudes regarding deportation versus applying for legal status. This is found across all candidate trait assessments when the full sample of respondents is analyzed. The results also hold when we examine the responses of only the Anglo respondents involved in our experiment. This means that Anglo respondents respond just as positively to the Latino candidate as the entire respondent pool. Interestingly, the pro-immigration treatment also results in a significant finding, suggesting that exposure to statements in support of more lenient positions on immigration led respondents to rate candidates more positively. 
Table 1. Multivariate analysis of candidate ethnicity and message on immigration-related traits

\begin{tabular}{|c|c|c|c|c|c|c|c|c|}
\hline \multirow[b]{2}{*}{ Traits: } & \multicolumn{2}{|c|}{$\begin{array}{l}\text { 1. Strong leader on } \\
\text { immigration }\end{array}$} & \multicolumn{2}{|c|}{$\begin{array}{l}\text { 2. Qualified to discuss } \\
\text { immigration }\end{array}$} & \multicolumn{2}{|c|}{$\begin{array}{l}\text { 3. Trustworthy on } \\
\text { immigration }\end{array}$} & \multicolumn{2}{|c|}{$\begin{array}{l}\text { 4. Experienced on } \\
\text { immigration }\end{array}$} \\
\hline & All resp. & Anglo resp. & All resp. & Anglo resp. & All resp. & Anglo resp. & All resp. & Anglo resp. \\
\hline \multicolumn{9}{|l|}{ Treatments } \\
\hline Latino candidate & $.33(.12)^{*}$ & $.49(.14)^{* * 2}$ & $.34(.12)^{* *}$ & $.44(.15)^{* *}$ & $.20(.12)+$ & $.31(.14)^{* *}$ & $.38(.11)^{\text {次 }}$ & $.47(.14)^{*}$ \\
\hline Pro-immigration & $.27(.12)^{* *}$ & $.16(.14)$ & $.55(.12)^{*}$ & $.42(.14)^{* *}$ & $.47(.12)^{* / 2}$ & $.30(.14)^{*}$ & $.46(.11)^{* *}$ & $.36(.14)^{* *}$ \\
\hline \multicolumn{9}{|l|}{ Controls } \\
\hline Republican & $-.09(.05)^{* *}$ & $-.08(.05)$ & $-.03(.05)$ & $.02(.05)$ & $-.14(.05)$ & $.00(.05)$ & $-.01(.04)$ & $.04(.05)$ \\
\hline Female & $.05(.11)$ & $-.03(.14)$ & $.01(.11)$ & $-.10(.13)$ & $-.07(.11)$ & $-.19(.14)$ & $-.14(.11)$ & $-.26(.13)+$ \\
\hline Income & $-.04(.04)$ & $.04(.06)$ & $-.01(.05)$ & $.07(.06)$ & $-.04(.04)$ & $.00(.06)$ & $-.02(.04)$ & $.03(.06)$ \\
\hline$R$ is Latino & $.07(.24)$ & - & $.29(.25)$ & - & $.10(.25)$ & - & $.21(.24)$ & - \\
\hline Believes in deport & $.01(.07)$ & $-.05(.08)$ & $.11(.07)$ & $.06(.09)$ & $.09(.07)$ & $.03(.09)$ & $.16(.07)^{* *^{*}}$ & $.12(.08)$ \\
\hline Pseudo $R^{2}$ & .0249 & .0286 & .04 & .0368 & .0264 & .0192 & .0373 & .0374 \\
\hline Prob $>$ chi $^{2}$ & .000 & .000 & .000 & .000 & .000 & .0411 & .000 & .000 \\
\hline N & 358 & 252 & 358 & 252 & 358 & 252 & 358 & 252 \\
\hline
\end{tabular}

Note: resp. = respondents. An ordered probit analysis of respondent assessment of the candidate traits specifically as they are related to the candidate on the issue of immigration: "strong leader," "qualified to discuss," "trusted," and "experienced," on a five-point scale with 1 as low scores and 5 as high scores on each trait. The first column under each trait presents the full sample of respondents, while the second column for each trait limits the analysis to Anglo respondents only. * $p<.05$. $+p<.10$. 
How might we explain the significant effects of pro-immigration messages on positive evaluations? Since our models controlled for partisanship and prior immigration attitudes, respondents most likely are not using their own personal biases to project their political or personal preferences into the attitude formation process, meaning the message and evaluation are not linked because respondents approve of the particular message being given. We also know that this effect is not explained by whether the respondent is female, has a certain income, or identifies as Latino, since our models also control for all of these measures. This puzzle led us to take a deeper look into the data to determine if there were any more specific treatment group effects driving the significant findings of these message effects. We therefore examined the predicted probabilities based on the ordered probit analysis in Table 1, to determine the size of each factor's effect, and also to examine whether these factors' ability to affect candidate evaluations were conditional upon each other. Looking at the predicted probabilities can tell us whether a candidate needs to be both Latino and hold pro-immigration messages to benefit from the issue of immigration, or whether each factor on its own can result in a net advantage when candidates discuss the issue of immigration.

The predicted probabilities presented in Figure 2 suggest that both candidate ethnicity and message content have a strong independent influence on a candidate's probability of receiving positive evaluations on the issue of immigration. These probabilities are based on the likelihood that a typical respondent of our survey will voice an evaluation that is more positive than negative or neutral, while holding all control variables at their mean values. Figure 2 compares the varying probability that a typical respondent of our survey voices a more positive evaluation when exposed to the four different treatments. Probabilities range from 0 , meaning there is no chance that the respondent will voice a positive evaluation, to 1 , meaning there is complete certainty that the respondent will voice a positive evaluation. A probability of .50 means that the respondent is equally as likely to voice a positive evaluation as a negative evaluation; the probability of a positive evaluation is therefore indistinguishable from a random event. The predicted probabilities demonstrate overall that a Latino candidate can benefit from the association individuals make with Latinos and the issue of immigration, resulting in more positive evaluations, and also that Latino candidates and Anglo candidates both stand to benefit if they simply voice pro-immigration stances.

The figure illustrates these effects, first, by showing that all Latino treatments resulted in an increase in the probability of a positive score within a 


\section{Strong leader on immigration}

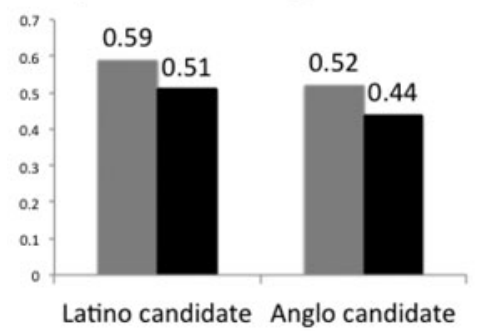

Trustworthy on immigration

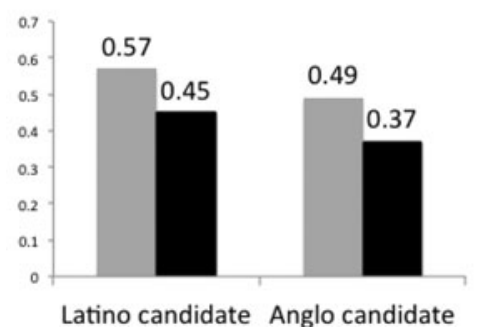

Qualified to discuss immigration

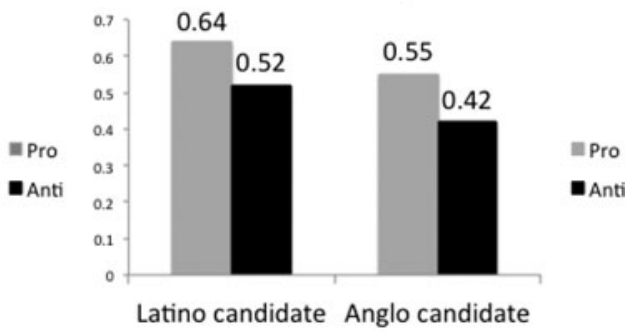

\section{Experienced on immigration}
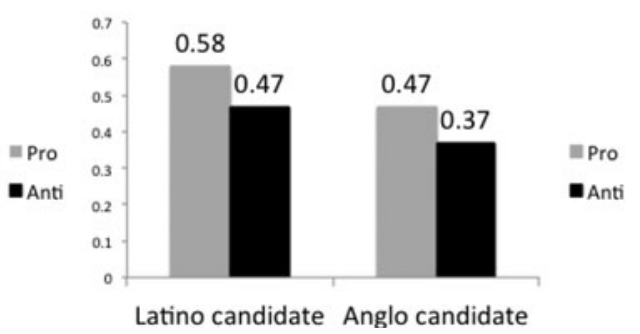

Figure 2. Predicted probabilities of positive trait evaluations, by candidate ethnicity and message delivered.

Notes: Probabilities were generated by holding all other variables at their mean values. The different column sizes illustrate the change in the probability that an average survey respondent would express a positive-as opposed to negative or neutral-candidate evaluation, when moving across the four different treatment groups. These probabilities were generated using the full sample of survey respondents.

range of .10-.15, regardless of message content. A "positive score," is defined as a respondent rating a candidate more positively than negatively (i.e., "strongly agree and agree" versus "disagree and strongly disagree" with a positive candidate evaluation). In the pro-immigration treatments, the probability of receiving a positive score goes from probabilities near .50 of receiving a positive score for the Anglo candidate, to a .60 probability of receiving a positive score if that candidate stays the same in every respect except for now being portrayed as a Latino candidate. The same sized increase in probability is uncovered when examining within the antiimmigration treatments. Moving from the Anglo candidate treatments to the Latino candidate treatments results in a corresponding shift in probabilities of a positive score from roughly .40 to .50 . Again, these differences result in a consistent gain in probability of .10 just by replacing an Anglo candidate with a Latino candidate. The figure, however, does not solely indicate a Latino ownership effect. It also illustrates a similar advantage 
from pro-immigration message content, with a consistent positive difference in the probability of positive scores (an average increase >.10) when respondents are exposed to pro-immigration stances, regardless of candidate ethnicity. For Anglo candidate treatments, this increase starts with probabilities in the range of .37-.44 of a positive score when the antiimmigration stance is delivered and shifts up a range of .44-.55 when the message switches to a pro-immigration stance. For Latino candidate treatments, Figure 2 exposes a similar increase in probability levels, although starting at a higher probability range (.47-.52) of a positive score when anti-immigration stances were delivered, increasing to the highest probability range of the entire experiment, .57-.64, once a pro-immigration stance is presented. Just as changing the ethnicity of the candidate from Anglo to Latino resulted in a consistent advantage in receiving a positive score by a .10 probability, regardless of message content, pro-immigration messages resulted in over a .10 probability advantage over anti-immigration messages, regardless of ethnicity. These findings suggest that both Latino ethnicity and pro-immigration message content resulted in independent positive effects on respondent evaluations of the candidate.

When employed together, Latino ethnicity and pro-immigration stances therefore increased candidate evaluations on the issue of immigration by a probability of just under .20. This would suggest that both types of information are able to influence candidate evaluations in a significant and substantial way. When both are present, the probability of scoring high marks on the issue of immigration is dramatically higher than when both are absent from a candidacy. Importantly, these findings indicate that a candidate's ability to achieve higher evaluations on the issue of immigration is not conditional upon both factors being present. However, it certainly helps a candidate's chances of being perceived positively on the issue when both factors are present.

The results reveal that the Latino and pro-Immigration treatments outperformed all other explanations in an ordered probit analysis. Upon further analysis, it was also shown that these factors were independently exerting an influence on candidate assessments. Taken together, we can surmise that both the source of the message and the message content matter, when determining how a candidate will be evaluated on the issue of immigration. While a candidate can benefit from one factor on its own, the findings reveal that when the right mixture of messenger ethnicity (e.g., Latino candidates) and message content are present (e.g., pro-immigration messages), they can produce dramatically higher evaluations of candidates on the issue of immigration, the order of magnitude of 
which is an increase of a .30 probability of a candidate receiving a positive evaluation in this issue area.

\section{CONCLUSION}

Across all respondents in general and in the minds of the Anglo respondents in particular, Latino candidates are perceived more positively on immigration than Anglo candidates who make claims that are either pro-immigration or anti-immigration. A Latino candidate who is pro-immigration will be perceived more positively (across a variety of immigration-related traits) than a Latino candidate who is anti-immigration. The findings suggest that the association of Latinos with immigration, an association noted for its prejudicial implications (Hopkins, Tran, and Williamson 2014; Valentino, Brader, and Jardina 2013), can yield positive evaluations for Latino candidates. These evaluations could be used strategically in the context of a campaign. Latino candidates, especially those delivering a pro-immigration message, can own this issue on the campaign trail. This issue builds perceptions of experience, strength of leadership on legislation, trust, and qualification to discuss the issue. Such traits might shape the minds of voters in ways similar to co-partisanship or co-ethnicity.

The finding of an association between Latinos and immigration is not new. Our study is nonetheless one of the first to our knowledge to reveal how Latino candidates might benefit in terms of public evaluations. Past scholarship has demonstrated this association as a symptom of the already stereotypical attitudes Anglo Americans harbor for Latinos in general (i.e., Valentino, Brader, and Jardina 2013). For instance, various studies point out that Americans, particularly Anglos, conflate the terms "immigrant," "Latino," and "Mexican" while drawing on these (often negatively depicted) associations to support more restrictive immigration policies (Knoll, Redlawsk, and Sanborn 2011; Ramakrishnan, Esterling, and Neblo 2009). Our findings are consistent with these studies' conclusions regarding Anglo Americans' stereotypical associations of Latinos with the issue of immigration, although we find that the association yields positive attitudinal benefits for Latino candidates in terms of a variety of trait scores on the issue.

Our findings also add to the broader literature on issue ownership, which to date has focused primarily on political parties and to a much lesser extent on how candidates with specific demographic or biographical traits might be able to own issues. We show here how the concept of issue 
ownership can be extended to ethnicity on the campaign trail, illustrating how Latino candidates build support beyond co-partisans and co-ethnics by association with the issue of immigration. The fact that immigration remains on the political agenda across the United States should create continuing opportunities for Latino candidates.

Our results imply that talking about immigration could be a viable campaign strategy for Latino candidates, increasing their favor with the public during the course of a political campaign. A greater emphasis placed on immigration should result in a consideration of traits that drives more positive evaluations for the Latino candidate. At the very least, bringing up the topic of immigration should lead to more positive discussions about Latino candidates and their skills on campaign issues, not negative discussions as has previously been hypothesized. These findings might cause us to reconsider the reach of literature suggesting that racializing campaigns should be avoided (Juenke and Sampaio 2010; Mendelberg 2001; Stuckey, Curry, and Barnes 2010). The question of whether Latino candidates could effectively prime the issue of immigration in a way that would affect the voting calculus of American voters remains outside the scope of this study. Future research should focus on dependent variables related to voting instead of traits like we have chosen to do here. Future research could also manipulate other candidate characteristics to see how our findings are attenuated; for example, while our study focuses on Democratic candidates, a replication could focus on Republican candidates to determine if respondents perceive these Latino and Anglo office-seekers any differently in their attempts to own the issue. Finally, future research should test such questions across different electoral contexts; our experiment took place in a state where Latinos count for less than $10 \%$ of the population but are a growing presence. Overall though, our analyses have provided a first test to the assumption of Latino ownership of the issue of immigration, which was necessary in order to build upon this knowledge to ask more involved questions about priming effects. We expect this research would find that under certain circumstances, priming immigration would in fact benefit Latino candidates across a campaign and on Election Day.

The findings here also importantly open doors for research on racial identity and issue ownership. Earlier studies demonstrated clear evidence of partisan issue ownership. And, these insights have been extended into the gender and politics literature, with extant research concluding that women candidates can similarly "own" issues such as education and poverty alleviation. Our research has been able to show that racially 
defined issue ownership can also influence candidate evaluations, which in turn can benefit racial/ethnic minority candidates. Future research should examine whether other racial/ethnic minority groups associated with immigration, such as Asian candidates, might also own immigration and benefit in the same manner. Additionally, there is still much research needed to address whether other racial groups "own" issues beyond the issue of immigration. For example, do Black Americans "own" any issues? There is a wealth of evidence to suggest that many Americans inextricably link Black Americans to welfare (Gilens 1999) - is it possible that Black candidates might benefit from these types of stereotypical associations in the context of the campaign? Do other issues advantage specific racial group members who decide to run for office? More research is needed to definitely uncover the full range of how racial identity interacts with issue ownership to influence public opinion and electoral dynamics in the United States.

\section{ACKNOWLEDGEMENTS}

Previous versions of this manuscript were presented at the 2013 Southern Political Science Association, 2013 Western Political Science Association, and 2014 Midwest Political Science Association conferences. We thank our discussants at these meetings, as well as manuscript reviewers, for their comments. We also thank Mackenzie Israel-Trummel and Keith Gaddie for their insights during the revision process. Any mistakes within the manuscript are those of the authors.

\section{NOTES}

1. As Druckman and Kam (2011) argue, using student subjects (as we do here) does not "intrinsically pose a problem for a study's external validity" or limit the ability to make inferences from an experiment, creating a problem "only when the size of an experimental treatment effect depends upon a characteristic on which the convenience sample has virtually no variance." We find no reason to believe this might be the case regarding this sample. Authors like Krupnikov and Levine (2014) and Mullinix et al. (2015) also find samples of convenience (like ours) resemble and are affected by information in similar ways as national representative samples. Additionally, a large majority of these students took part in this experiment in introductory American Government courses, which are required of all students at this university regardless of major. Such a requirement should lessen fears that our respondent pool is more interested in politics than a random pool of respondents drawn from the general public.

2. Our respondent pool roughly approximates the American public in terms of most demographic traits. In comparison with the American population in general, Anglos, males, Republicans, and members of higher income families were slightly overrepresented in our sample. However, most of these percentages did not diverge significantly from the general American population, and ultimately there is no evidence to suggest biased findings would result from the student sample's demographic and political makeup. Demographic specifics of the pool of survey respondents can be obtained from the authors upon request. 
3. Whereas we use the terms undocumented immigrant and undocumented immigration at points throughout the manuscript, we use the vernacular of the mainstream press in the actual experimental treatments (and the in-text discussion of the treatments as well): illegal immigrant and illegal immigration. This provides realism to the mock news article (see Greenfield 2006 and Soderlund 2007 for a discussion of the damaging and derogatory influence of using the term "illegal" instead of "undocumented" immigrants).

4. We purposely chose to set the particulars of our fictional race in a location with some distance from where the experiment was taking place so as to deter participants from allowing existing knowledge about local or state politics and politicians to affect their responses.

5. Our approach mirrors previous studies that employ similar experimental designs. Most of these studies examine the effect of racial and ethnic cues on prejudicial evaluations, in economics and politics. Rather than developing the race or ethnicity of the treatments beyond the name, these studies similarly find significant effects based on this important yet minimal cue-the name.

6. References to higher education and tuition rates in the treatments potentially add greater resonance of candidate conversations to our sample of undergraduate college students.

7. We use two commonly studied traits (according to McGraw 2011) in our analysis: leadership and integrity (which we measure as trustworthiness). We also include qualification and experience based on gender literature showing that female candidates are often evaluated on these traits when speaking on issues seen as relevant to women (Kahn 1993; Sanbonmatsu 2002).

8. Interestingly, these same patterns hold for general traits (not specifically related to the candidate's handling of immigration), although these differences are more variable and less statistically significant.

9. A figure of the significant results from the ANOVA tests is located in Appendix D.

10. The comparisons are based on a measure of candidate favorability from 1 to 5 , where 1 represents unfavorable assessments of candidates, 3 represents neutral assessments, and 5 represents favorable assessments of candidates (i.e., specifically on their handling of immigration).

\section{REFERENCES}

Abosch, Yishaiya, Matt Barreto, and Nathan Woods. 2007. "An Assessment of Racially Polarized Voting For and Against Latino Candidates in California." In Voting Rights Act Reauthorization of 2006: Perspectives on Democracy, Participation, and Power, ed. Ana Henderson. Berkeley, CA: UC Berkeley Public Policy Press, pp. 107-31.

Abrajano, Marisa, Jonathan Nagler, and R. Michael Alvarez. 2005. "Race-Based versus Issue-Based Voting-A Natural Experiment: The 2001 City of Los Angeles Elections." Political Research Quarterly 58: 203-18.

Alexander, Deborah, and Kristi Andersen. 1993. "Gender as a Factor in the Attribution of Leadership Traits." Political Research Quarterly 46: 527-45.

Allport, Gordon. 1954. The Nature of Prejudice. Cambridge, MA: Addison-Wesley Pub. Co.

Ansolabehere, Stephen, and Shanto Iyengar. 1994. "Riding the Wave and Claiming Ownership Over Issues: The Joint Effects of Advertising and News Coverage in Campaigns." Public Opinion Quarterly 58: 335-57.

Arceneaux, Kevin, and Robin Kolodny. 2007. "The Messenger or the Message? Group Endorsements, Heuristics, and Grassroots Campaigning." Presented at the Annual Meeting of the American Political Science Association, Chicago, IL.

Banducci, Susan, Todd Donovan, and Jeffrey Karp. 2004. "Minority Representation, Empowerment, and Participation." Journal of Politics 66: 534-56.

Barreto, Matt. 2007a. "Sí Se Puede! Latino Candidates and the Mobilization of Latino Voters." American Political Science Review 101: 425-41.

Barreto, Matt. 2007b. "The Role of Latino Candidates in Mobilizing Latino Voters: Revisiting Latino Vote Choice." In Latino Politics: Identity, Mobilization, and Representation, eds. Rodolfo Espino, David Leal, and Kenneth Meier. Charlottesville: University of Virginia Press. 
Barreto, Matt. 2010. Ethnic Cues: The Role of Shared Ethnicity in Latino Political Participation. Ann Arbor, MI: University of Michigan Press, pp. 63-89.

Barreto, Matt, Gary Segura, and Nathan Woods. 2004. "The Mobilizing Effect of Majority-Minority Districts on Latino Turnout." American Political Science Review 98: 65-75.

Belanger, Eric. 2003. "Issue Ownership by Canadian Political Parties 1953-2001." Canadian Journal of Political Science 36: 539-58.

Bertrand, Marianne and Sendhil Mullainathan. 2004. "Are Emily and Greg More Employable Than Lakisha and Jamal? A Field Experiment on Labor Market Discrimination.” American Economic Review 94: 991-1013.

Bobo, Lawrence, and Franklin D. Gilliam Jr. 1990. "Race, Sociopolitical Participation, and Black Empowerment." American Political Science Review 84: 377-93.

Brewer, Marilyn B. 1999. “The Psychology of Prejudice: Ingroup Love or Outgroup Hate?” Journal of Social Issues 55 (3): 429-44.

Budge, Ian, and Dennis Farlie. 1983. "Party Competition-Selective Emphasis or Direct Confrontation: An Alternative View with Data." In Western European Party Systems, eds. Hans Daalder, and Peter Mair. London: Sage, pp. 267-305.

Butler, Daniel M. and David E. Broockman. 2011. "Do Politicians Racially Discriminate Against Constituents? A Field Experiment on State Legislators?” American Journal of Political Science 55: 463-77.

Campbell, Angus, Philip Converse, Warren E. Miller, and Donald Stokes. 1960. The American Voter. New York: John Wiley.

Carlsson, Magnus, and Dan-Olof Rooth. 2007. "Evidence of Ethnic Discrimination in the Swedish Labor Market Using Experimental Data.” Labour Economics 14: 716-29.

Citrin, Jack, Donald Green, Christopher Muste, and Cara Wong. 1997. "Public Opinion Toward Immigration Reform: The Role of Economic Motivations." Journal of Politics 59: 858-81.

Conover, Pamela Johnston. 1984. "The Influence of Group Identifications on Political Perception and Evaluation." Journal of Politics 46: 760-85.

Converse, Philip. 1964. "The Nature of Belief Systems in Mass Politics." In Ideology and Discontent, ed. David Apter. New York: Free Press, pp. 1-74.

Converse, Philip. 1990. "Popular Representation and the Distribution of Information." In Information and Democratic Processes, eds. John Ferejohn, and James Kuklinski. Urbana, IL: University of Illinois Press, pp. 369-88.

Damore, David. 2004. "The Dynamics of Issue Ownership in Presidential Campaigns." Political Research Quarterly 57: 391-97.

Dawson, Michael C. 1994. Behind the Mule: Race and Class in African-American Politics. Princeton, NJ: Princeton University Press.

Delli Carpini, Michael X., and Scott Keeter. 1996. What Americans Know about Politics and Why it Matters. New Haven, CT: Yale University Press.

Doherty, David. 2008. "Presidential Rhetoric, Candidate Evaluations, and Party Identification: Can Parties ‘Own' Values?” Political Research Quarterly 61: 419-33.

Druckman, James D. 2004. "Political Preference Formation: Competition, Deliberation, and the (Ir)relevance of Frame Effects." American Political Science Review 98: 671-86.

Druckman, James N. and Cindy D. Kam. 2011. "Students as Experimental Participants: A Defense of the 'Narrow Data Base'." In Handbook of Experimental Political Science, eds. James N. Druckman, Donald P. Green, James H. Kuklinski, and Arthur Lupia. New York: Cambridge University Press, 41-57.

Dulio, David A., and Peter F. Trumbore. 2009. "Running on Iraq or Running from Iraq? Conditional Issue Ownership in the 2006 Midterm Elections." Political Research Quarterly 62: 230-43. 
Fridkin, Kim L., and Patrick J. Kenney. 2009. “The Role of Gender Stereotypes in U.S. Senate Campaigns." Politics \& Gender 5: 301-24.

Fryer, Roland G. Jr., and Steven D. Levitt. 2004. "The Causes and Consequences of Distinctively Black Names." Quarterly Journal of Economics 119: 767-805.

Gilens, Martin. 1999. Who Do Americans Hate Welfare? Chicago: The University of Chicago Press.

Gilens, Martin. 2001. "Political Ignorance and Collective Policy Preferences." American Political Science Review 95: 379-96.

Goble, Hannah, and Peter Holm. 2009. "Breaking Bonds? The Iraq War and the Loss of Republican Dominance in National Security." Political Research Quarterly 62: 215-29.

Green, Donald, Bradley Palmquist, and Erick Schickler. 2004. Partisan Hearts and Minds: Political Parties and the Social Identities of Voters. New Haven, CT: Yale University Press.

Greenfield, Jeff. 2006. “Defining the Immigration Debate.” CNN. http://www.cnn.com/ 2006/POLITICS/04/14/greenfield.immigration/.

Hayes, Danny. 2005. "Candidate Qualities through a Partisan Lens: A Theory of Trait Ownership." American Journal of Political Science 49: 908-23.

Hayes, Danny. 2010. "Trait Voting in U.S. Senate Elections." American Politics Research 38: 1102-29.

Herrnson, Paul S., J. Celeste Lay, and Atiya Kai Stokes. 2003. "Women Running 'as Women': Candidate Gender, Campaign Issues, and Voter-Targeting Strategies." Journal of Politics 65: 244-55.

Holbrook, Colin, Daniel M. T. Fessler, and Carlos David Navarrete. 2016. "Looming Large in Others' Eyes: Racial Stereotypes Illuminate Dual Adaptations for Representing Threat Versus Prestige as Physical Size." Evolution and Human Behavior 37: 67-78.

Holian, David B. 2004. "He's Stealing My Issues! Clinton's Crime Rhetoric and the Dynamics of Issue Ownership." Political Behavior 26: 95-124.

Hopkins, Daniel J., Van C. Tran, and Abigail Fisher Williamson. 2014. "See No Spanish: Language, Local Context, and Attitudes Toward Immigration.” Politics, Groups, and Identities 2 (1): 35-51.

Hovland, Carl I., Irving L. Janis, and Harold H. Kelley. 1953. Communication and Persuasion: Psychological Studies of Opinion Change. New Haven, CT: Yale University Press.

Huddy, Leonie, and Nayda Terkildsen. 1993. "Gender Stereotypes and the Perception of Male and Female Candidates." American Journal of Political Science 37: 119-47.

Israel-Trummel, Mackenzie. N.d. "Facing a Black Woman: the Irrational Response to Underperforming White Male Incumbents" [unpublished manuscript].

Iyengar, Shanto, and Nicholas Valentino. 2000. "Who Says What? Source Credibility as a Mediator of Campaign Advertising." In Elements of Reason: Cognition, Choice, and the Bounds of Rationality, eds. Arthur Lupia, Matthew McCubbins, and Samuel Popkin. New York: Cambridge University Press, pp. 108-27.

Juenke, Eric Gonzalez, and Anna Christina Sampaio. 2010. "Deracialization and Latino Politics: The Case of the Salazar Brothers in Colorado." Political Research Quarterly 63: 43-54.

Kahn, Kim Fridkin. 1992. "Does Being Male Help? An Investigation of the Effects of Candidate Gender and Campaign Coverage on Evaluations of U.S. Senate Candidates." Journal of Politics 54: 497-517.

Kahn, Kim Fridkin. 1993. "Gender Differences in Campaign Messages: The Political Advertisements of Men and Women Candidates for US Senate.” Political Research Quarterly 46: 481-502. 
Kam, Cindy D. 2007. "Implicit Attitudes, Explicit Choices: When Subliminal Priming Predicts Candidate Preference." Political Behavior 29: 343-67.

Kaufmann, Karen M. 2004. "Disaggregating and Reexamining Issue Ownership and Voter Choice." Polity 36: 283-99.

Knoll, Benjamin R., David P. Redlawsk, and Howard Sanborn. 2011. "Framing Labels and Immigration Policy Attitudes in the Iowa Caucuses: "Trying to Out-Tancredo Tancredo'." Political Behavior 33: 433-54.

Koch, Jeffrey. 1999. "Candidate Gender and Assessments of Senate Candidates." Social Science Quarterly 80: 84-96.

Koch, Jeffrey. 2000. "Do Citizens Apply Gender Stereotypes to Infer Candidates' Ideological Orientations?" Journal of Politics 62: 414-29.

Krupnikov, Yanna, and Adam Seth Levine. 2014. "Cross-Sample Comparisons and External Validity." Journal of Experimental Political Science 1: 59-80.

Kuklinski, James, and Norman Hurley. 1994. "On Hearing and Interpreting Political Messages: A Cautionary Tale of Citizen Cue-Taking." Journal of Politics 56: 729-51.

Lau, Richard, and David Redlawsk. 2001. "Advantages and Disadvantages of Cognitive Heuristics in Political Decision Making." American Journal of Political Science 45: 951-71.

Lawless, Jennifer. 2004. "Women, War, and Winning Elections: Gender Stereotyping in the Post-September 11th Era." Political Research Quarterly 57: 479-90.

Leighley, Jan. 2001. Strength in Numbers? The Political Mobilization of Racial and Ethnic Minorities. Princeton, NJ: Princeton University Press.

Lodge, Milton, Kathleen McGraw, and Patrick Stroh. 1989. “An Impression-Driven Model of Candidate Evaluation.” American Political Science Review 83: 399-419.

Manzano, Sylvia, and Gabriel R. Sanchez. 2010. "Take One for the Team? Limits of Shared Ethnicity and Candidate Preferences." Political Research Quarterly 63: 568-80.

Masuoka, Natalie, and Jane Junn. 2013. The Politics of Belonging: Race, Public Opinion, and Immigration. Chicago: The University of Chicago Press.

Matson, Marsha and Terri Susan Fine. 2006. "Gender, Ethnicity, and Ballot Information: Ballot Cues in Low-Information Elections." State Politics \& Policy Quarterly 6: 49-72.

McDermott, Monika. 1997. "Voting Cues in Low-Information Elections: Candidate Gender as a Social Information Variable in Contemporary United States Elections." American Journal of Political Science 41: 270-83.

McDermott, Monika. 1998. "Race and Gender Cues in Low Information Elections." Political Research Quarterly 51: 895-918.

McGraw, Kathleen. 2011. "Candidate Impressions and Evaluations." In Cambridge Handbook of Experimental Political Science, eds. James N. Druckman, Donald P. Green, James H. Kuklinski, and Arthur Lupia. Cambridge: Cambridge University Press, 187-200.

McIlwain, Charlton D., and Stephen M. Caliendo. 2011. Race Appeal: How Candidates Invoke Race in U.S. Political Campaigns. Philadelphia: Temple University Press.

Mendelberg, Tali. 2001. The Race Card: Campaign Strategy, Implicit Messages, and the Norm of Equality. Princeton, NJ: Princeton University Press.

Mullinix, Kevin J., Thomas J. Leeper, James N. Druckman, and Jeremy Freese. 2015. "The Generalizability of Survey Experiments." Journal of Experimental Political Science 2: 109-38.

Nelson, Thomas and Jennifer Garst. 2005. "Values-based Political Messages and Persuasion: Relationships Among Speaker, Recipient, and Evoked Values." Political Psychology 26: 489-516. 
Oreopoulos, Philip. 2011. "Why Do Skilled Immigrants Struggle in the Labor Market? A Field Experiment with Thirteen Thousand Resumes." American Economic Journal: Economic Policy 3: 148-71.

Petrocik, John. 1996. "Issue Ownership in Presidential Elections, with a 1980 Case Study." American Journal of Political Science 40: 825-50.

Petrocik, John R., William L. Benoit, and Glenn J. Hansen. 2003. "Issue Ownership and Presidential Campaigning, 1952-2000.” Political Science Quarterly 118: 599-626.

Pew. 2009. "Between Two Worlds: How Young Latinos Come of Age in America." http:// www.pewhispanic.org/files/reports/117.pdf.

Pope, Jeremy C., and Jonathan Woon. 2009. "Measuring Changes in American Party Reputations, 1939-2004.” Political Research Quarterly 62: 653-61.

Rahn, Wendy. 1993. "The Role of Partisan Stereotypes in Information Processing about Political Candidates." American Journal of Political Science 37: 472-96.

Ramakrishnan, Karthick, Kevin Esterling, and Michael Neblo. 2009. "Illegality, National Origin Cues, and Public Opinion on Immigration." Working paper.

Riach, Peter A., and Judith Rich. 2002. "Field Experiments of Discrimination in the Market Place." Economic Journal 112: 480-513.

Sanbonmatsu, Kira. 2002. "Gender Stereotypes and Vote Choice." American Journal of Political Science 46: 20-34.

Sellers, Patrick J. 1998. "Strategy and Background in Congressional Campaigns.” American Political Science Review 92: 159-71.

Sigelman, Carol K., Lee Sigelman, Barbara J. Walkosz, and Michael Nitz. 1995. "Black Candidates, White voters: Understanding Racial Bias in Political Perceptions." American Journal of Political Science 39: 243-65.

Soderlund, Monica. 2007. "The Role of News Media in Shaping and Transforming the Public Perception of Mexican Immigration and the Laws Involved." Law \& Psychology Review 31: 167-77.

Stubager, Rune and Rune Slothuus. 2013. "What Are the Sources of Political Parties' Issue Ownership? Testing Four Explanations at the Individual Level.” Political Behavior 35: 567-88.

Stuckey, Mary E., Kristina E. Curry, and Andrew E. Barnes. 2010. "Bringing Candidacies in from the Cold: Mainstreaming Minority Candidates 1960 and 2008." Presidential Studies Quarterly 40: 414-30.

Tajfel, Henri. 1981. "Social Stereotypes and Social Groups." In Intergroup Behaviour, eds. John C. Turner, and Howard Giles. Oxford, UK: Blackwell, 144-67.

Tate, Katherine. 1993. From Protest to Politics: The New Black Voters in American Elections. Cambridge, MA: Harvard University Press.

Terrero, Nina. 2012. "Record Number of Latinos in Congress." NBC Latino. http:// nbclatino.com/2012/11/07/race-recap-2012-latino-congressional-winners-and-losers/.

U.S. Census. 2010. http://www.census.gov/2010census/.

Valentino, Nicolas A., Ted Brader, and Ashley E. Jardina. 2013. "Immigration Opposition Among U.S. Whites: General Ethnocentrism or Media Priming of Attitudes About Latinos?" Political Psychology 34: 149-66.

Walgrave, Stefaan, Jonas Lefevere, and Michiel Nuytemans. 2009. "Issue Ownership Stability and Change: How Political Parties Claim and Maintain Issues Through Media Appearances." Political Communication 26: 153-72.

Walgrave, Stefaan, Jonas Lefevere, and Anke Tresch. 2012. "The Associative Dimension of Issue Ownership.” Public Opinion Quarterly 76: 771-82.

Zaller, John and Stanley Feldman. 1992. "A Simple Theory of the Survey Reponse: Answering Questions versus Revealing Preferences." American Journal of Political Science 36: 579-616. 


\section{APPENDIX}

\section{Appendix A: Pre-Treatment Questions}

The following are the pre-treatment questions used in the multivariate model in Table 1. A full set of pre-treatment questions is available from the authors upon request.

What is your gender?

(A) Female, (B) Male

What racial group do you consider yourself to be a part of?

(A) African American, (B) Asian American, (C) Caucasian, (D) Latino, (E) Other

Generally speaking, do you usually think of yourself as a Democrat, Republican, Independent, or what?

(A) Strong Democrat, (B) Not Very Strong Democrat, (C) Independent, (D) Not Very Strong Republican, (E) Strong Republican

Which of the following categories best describes your family's annual income?

(A) Under 25,000, (B) 25,000-49,999, (C) 50,000-74,999, (D) 75,000-99,999, (E) 100,000 or more

Do you think illegal immigrants who are living in the United States now should be offered a chance to keep their jobs and eventually apply for legal status, or do you think they should be deported back to their native country?

(A) Offered a chance, (B) Deported, (C) Unsure.

\section{Appendix B: Treatments}

The following are full examples of three of the five treatments participants in the survey experiment encountered. These three examples capture the two key manipulations (Latino name versus Anglo name, positivity versus negativity on the role of illegal immigrants) as well as the control.

Treatment 1: Latino name, pro-immigration

Ramírez to UMKC town hall: Illegal immigrants have "positive impact"

By EMILY BONNEAU, Associated Press

KANSAS CITY (AP)-At a town hall meeting Thursday at the University of Missouri-Kansas City, Democratic congressional candidate Luis Ramírez declared to attendees that illegal immigrants currently residing in the United States have "a positive impact on jobs for American citizens" and "a positive impact on the way of life in American communities." In a wide-ranging forum that touched on economic policy, job growth, education, and health care and the upcoming 2012 election, Ramírez said that should he win higher office, he would work tirelessly to find pathways for illegal immigrants to earn citizenship.

"When I won the Democratic primary in August, I promised not to shy away from the tough issues like immigration policy," Ramírez told the crowd of approximately 500 students, faculty, administrators, and locals. "The current system is keeping nuclear families apart. Currently, legal immigrants in America often have to wait years to be with husbands, wives, and young children," Ramírez stated. When pressed by moderators and audience members on what solutions the federal government should pursue, Ramírez suggested that the United States grant more visas to highly-skilled job creators and innovators to make up for labor shortages and gaps in skills. When asked about the state and local impact of illegal immigration, Ramírez argued that illegal immigrants only take jobs that 
Missouri workers don't want. He also argued that denying in-state tuition to the children of undocumented immigrants "excludes talented, qualified young adults from pursuing higher education" and that providing these young adults with access to higher education was "simply a wise investment in Missouri's future."

Ramírez, currently a three-term State Senator representing suburbs north and east of Kansas City, is the Democratic nominee for Missouri's 6th congressional district, which encompasses much of the northwest corner of the state.

Treatment 2: Anglo name, anti-immigration

Rooney to UMKC town hall: Illegal immigrants have "negative impact" By EMILY BONNEAU, Associated Press

KANSAS CITY (AP) - At a town hall meeting Thursday at the University of Missouri-

Kansas City, Democratic congressional candidate Robert Rooney declared to attendees that illegal immigrants currently residing in the United States have "a negative impact on jobs for American citizens" and "a negative impact on the way of life in American communities." In a wide-ranging forum that touched on economic policy, job growth, education, and health care and the upcoming 2012 election, Rooney said that should he win higher office, he would work tirelessly to stem the tide of illegal immigration.

"When I won the Democratic primary in August, I promised not to shy away from the tough issues like immigration policy," Rooney told the crowd of approximately 500 students, faculty, administrators, and locals. "A porous border allows illegal immigrants to enter the United States, violent cartel members and terrorists possibly among them. Many visitors ignore the terms of their visas and stay in the U.S. illegally," Rooney stated. When pressed by moderators and audience members on what solutions the federal government should pursue, Rooney suggested that businesses be required to verify the immigration status of workers and that pathways to citizenship for illegal immigrants be blocked. When asked about the state and local impact of illegal immigration, Rooney argued that illegal immigrants were taking jobs that could be filled by Missourians and earning in-state tuition benefits at colleges and universities despite their undocumented status. He also argued that "by offering in-state tuition rates to the children of undocumented immigrants, Missouri would be forced to offer in-state tuition rates to all U.S. citizens."

Rooney, currently a three-term State Senator representing suburbs north and east of Kansas City, is the Democratic nominee for Missouri's 6th congressional district, which encompasses much of the northwest corner of the state.

Treatment 3: no candidate name, no position taken on the role of illegal immigrants Candidate to UMKC town hall: "Illegal immigrants have impact"

By EMILY BONNEAU, Associated Press

KANSAS CITY (AP)-At a town hall meeting Thursday at the University of Missouri-Kansas City, a Democratic congressional candidate declared to attendees in a wide-ranging forum that touched on economic policy, job growth, education, and health care and the upcoming 2012 election, that "when I won the Democratic primary in August, I promised not to shy away from the tough issues like immigration policy." The candidate addressed a crowd of approximately 500 students, faculty, administrators, and locals and was pressed by moderators and audience members on what solutions related to immigration the federal government should pursue. He was also asked about the state and local impact of illegal immigration. 
The candidate is currently a three-term State Senator representing suburbs north and east of Kansas City and is the Democratic nominee for Missouri's 6th congressional district, which encompasses much of the northwest corner of the state.

Treatment 4: identical to Treatment 1, except all mentions of Luis Ramírez/Ramírez are changed to Robert Rooney/Rooney

Treatment 5: identical to Treatment 2, except all mentions of Robert Rooney/Rooney are changed to Luis Ramírez/Ramírez

\section{Appendix C: Post-Treatment Questions}

The following are the survey questions that comprise our dependent variables. A full set of pre-treatment questions is available from the authors upon request. Note that those receiving treatments asking about the Latino candidate answered these questions about Luis Ramírez and those who received the control answered these questions about "this congressional candidate."

How experienced do you think Robert Rooney is when it comes to the issue of immigration?
(A) Highly Inexperienced
(B) Inexperienced
(C) Neither Experienced Nor Inexperienced
(D) Experienced
(E) Highly Experienced

How qualified do you think Robert Rooney is when it comes to discussing the issue of immigration?
(A) Highly Unqualified
(B) Unqualified
(C) Neither Qualified Nor Unqualified
(D) Qualified
(E) Highly Qualified

How trustworthy do you think Robert Rooney is when it comes to the issue of immigration?
(A) Highly Untrustworthy
(B) Untrustworthy
(C) Neither Trustworthy Nor Untrustworthy
(D) Trustworthy
(E) Highly Trustworthy

If elected, how strong of a leader do you feel Robert Rooney would be when it comes to legislation dealing with immigration?
(A) Highly Weak
(B) Weak
(C) Neither Strong Nor Weak
(D) Strong
(E) Highly Strong 
Appendix D: ANOVA Figure

(a)

- Latino candidate

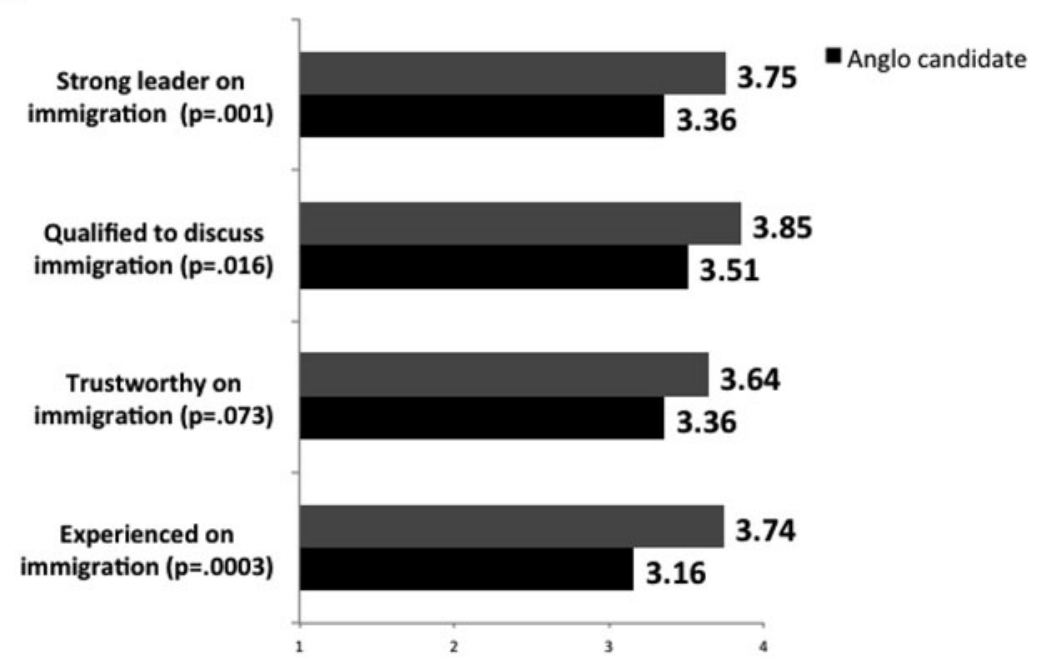

(b)

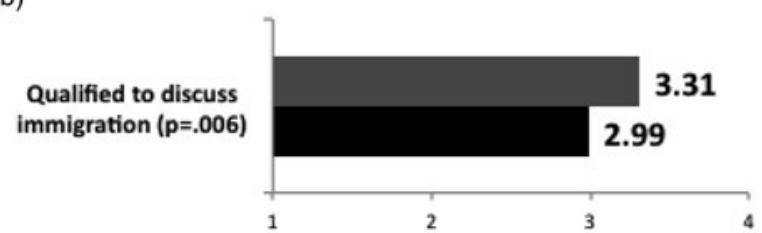

Figure D1. Presents the mean treatment scores given by the full sample of respondents surveyed, on a scale of 1 to $5 ; 1=$ lowest evaluation 5 = highest evaluation. All column graphs represent the difference in mean scores given by Latino and Anglo treatment groups, with (A) representing only those treatment groups who received the Pro-Immigration message treatment and (B) representing only those treatment groups who received the Anti-Immigration treatment. The figure presents significant (ANOVA) results only, for ease of exposition. 